\title{
腰痛が個人の生活（経済的, 心理的）に及ぼす影響
}

\author{
産業医科大学リハビリテーション科 \\ 森 田秀明 \\ 成尾整形外科病院（熊本） \\ 成尾 政 图・小柳 英一 \\ 浦門操
}

\section{Pre- and Postoperative Influences to the Individual Patients with Low Back Pain regarding to Socioeconomical and Psychological Aspects}

by

\section{H. Morita}

Department of Rehabilitation, School of Medicine, University of Occupational and Environmental Health, Kitakyushu 807.

\section{Naruo, E. Koyanagi and M. Urakado}

Naruo Orthopedic Hospital, Kumamoto 862.

Socioeconomical and psychological influences to the operated patients with low back pain were studied from 1976 to 1977 by means of questionnaires.

Operated patients had been heavily suffered from economical loss for average six to eight months of work-off time which was statistically correlated with the duration from admission to returning to work and the operated method. However, the loss was not related to the postoperative medical evaluation and the patient's satisfaction to the operation as of psychological reaction.

The fear of the recurrence was statistically forced their jobs into lighter work.

Posterior appooach for aged female was revealed to be made carefully for psychological problem.

\section{はじめに}

腰痛疾患関して, 従来その術後成績については, 純医学的側面からの報告がほとんどで, 経済的側面か ら検討した報告は見当らない。桐田は, 復職に関し て, 術後 6,7 ケ月を要し, 重より軽への転職は, 149 例中 7 例 $4.6 \%$ 完治して重への転職は, 9 例 $6 \%$ と述べ, Naylor は, 発症後手術までの期間と手術後 復職までの期間について述べ, 職業変更については, 204 人中 28 人 $13 \%$ \%，軽労働に転職し，その転職の 頻度は，手術之非手術的方法で差がなかったと報告し ているのに過ぎない，ある疾患に罹病したために当然 経済的損失を被むるのは致し方ないことであるが，治
療者側は，患者の経済的側面も考慮に入れて対処する のが，医は仁術之云われる所以であろうし，実際患者 がどの程度損失を受けているかを知ることは重要であ る. 何故なら個人の経済的損失を裹返せば，社会人が 払っている社会保険の損失であり，社会の経済的マイ ナスを反影している事になるからである. そこで今 回, 腰痛疾患に対して手術的治療を施行した症例につ き，経済的側面を検討してみた.

$$
\begin{gathered}
\text { 方 } \\
\text { アンケート調査項目は，1）罹病期間，2）外来通 }
\end{gathered}
$$
院治療期間，3）他院入院治療期間，4）当院入院治 療期間，5）退院後復職するまでの期間，6) 手術後 
の職業変更の有無とその労㗢の程度について, 8) 手 術に対する感想については，イ）大変満足している.

口）満足している.八）しないよりよかった. 二）し てもしなくてああまり変らない. 小）しない方がよか った.の 5 段階の満足度. 9) 桐田の成績判定基準の 中, 11 項目の残存腰部症状 +12 項目目に自由書きを 加えた合計 9 項目を質問し，無記名で回答してもらっ たが，てちらでは，回答者がわかるように暗号を付し た.

\section{結果}

アンケート調査数は 338 通で，回答数は 149 通その 中他疾患で 2 名死亡の通知を受け住所不明 29 通 が 返 信された. アンケート回収率としては，307 例中 147

(47.9\%)であった. 症例とその疾患の内訳は表 1 に 示す. 表中前方法とは，前方浸入し椎体固定術を施行 したもの, 後方法とは Love 法と Laminectomy に 䯣核摘出術を加えたものを意味する．前方法群は腰部 椎間板症, 过り症, 仮性过り症が主で, 後方法群で は，腰部脊椎管狭窄症と椎間板ヘルニアである.

年令別頻度と平均年令を表 2 に示す. 全症例では40 代 50 代 30 代 20 代の順に多かった. 前方法群の 男性
が最も若く（ $\mathrm{p}<0.01 ）$. 他は年令に有意差はない. 前方法群の女性 40 代 50 代で椎体固定してあるのは, 过り症や仮性之り症例であり，後方法群での高令者は 腰部脊椎管狭窄症例である.

職業別頻度（表 3 ）では，地域柄，農漁業が最多 で，次に工員大工，タクシーの運転手等腰部に負担の かかる職業が多い，主婦専業や無職は少数で，有職者 は，前方法群男性 $100 \%$ 女性 $80 \%$, 後方法群 男性 89 \%, 女性 $62 \%$ で，後方法群女性に有職率が低かった。 全症例では, $88.4 \%$ 有職率であった。 また, 経凧的 損得に関係する共働き（農漁業）之主婦の比率は，前 方法群男性 $12 \%$ ，女性 $55 \%$ ，後方法群男性 $31 \%$, 女性 $66 \%$ \%゙り，云わゆるサラリーマンは，前方法 群男性 $88.4 \%$, 女性 $42.5 \%$, 後方法群男性 $65.7 \%$, 女性 $27.6 \%$ であった。

罹病期間と外来通院治療期間については（表 4)， 術式，男女間，同性間に有意差はなかった。

他院入院期間については，術式では，前方法群の男 性のみは, 後方法に比して有意 $(\mathrm{p}<0.01)$ に短期間 であった，男女間では，前方法群の男性は，前方法や 後方法群の女性に比して有意 $(\mathrm{p}<0.01)$ に短期間で あった. 同性間では, 前方法群の男性が, 後方法群の

表 1 術式別疾患の内訳

\begin{tabular}{|c|c|c|c|c|c|c|}
\hline & 前 & 方 & 法 & \multicolumn{2}{|l|}{ 後 } & 法 \\
\hline & 男 & 女 & 計 & 男 & 女 & 計 \\
\hline 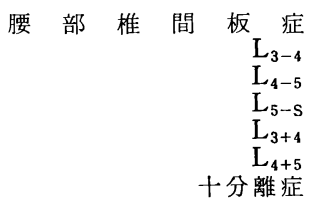 & $\begin{array}{r}2 \\
21 \\
2 \\
2 \\
2 \\
4\end{array}$ & $\begin{array}{r}17 \\
2 \\
2\end{array}$ & $\begin{array}{c}54 \\
(36.7 \%)\end{array}$ & $\begin{array}{l}6 \\
9\end{array}$ & $\begin{array}{l}1 \\
8 \\
1\end{array}$ & $\begin{array}{c}25 \\
(17.0 \%)\end{array}$ \\
\hline 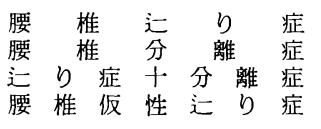 & $\begin{array}{l}6 \\
2 \\
1\end{array}$ & $\begin{array}{r}4 \\
1 \\
13\end{array}$ & $\begin{array}{c}27 \\
(18.4 \%)\end{array}$ & & & 0 \\
\hline 腰 椎 カ リ エ ス & 1 & 1 & $2(1.4 \%)$ & & & 0 \\
\hline $\begin{array}{r}\text { 腰部脊 椎管狭窄症 } \\
\text { 変性による } \\
+ \text { 少にこう } \\
\text { 術後による } \\
\text { 迄り症による }\end{array}$ & & & 0 & $\begin{array}{r}14 \\
5 \\
1\end{array}$ & $\begin{array}{r}13 \\
2 \\
1 \\
3\end{array}$ & $\begin{array}{c}39 \\
(25.5 \%)\end{array}$ \\
\hline 小 & $\begin{array}{c}43 \\
(29.3 \%)\end{array}$ & $\begin{array}{c}40 \\
(27.2 \%)\end{array}$ & $\begin{array}{c}83 \\
(56.5 \%)\end{array}$ & $\begin{array}{c}35 \\
(23.8 \%)\end{array}$ & $\begin{array}{c}29 \\
(19.7 \%)\end{array}$ & $\begin{array}{c}64 \\
(43.5 \%)\end{array}$ \\
\hline 計 & & & 147 & $0 \%)$ & & \\
\hline
\end{tabular}


表 2 年 令別頻度並びに平均年令

\begin{tabular}{|c|c|c|c|c|c|}
\hline & 前 & 法 & 後 & 法 & \multirow{2}{*}{ 計 } \\
\hline & 男 & 女 & 男 & 女 & \\
\hline $\begin{array}{l}10 \sim 19 才 \\
20 \sim 29 才 \\
30 \sim 39 才 \\
40 \sim 49 才 \\
50 \sim 59 才 \\
60 \sim 69 才\end{array}$ & $\begin{array}{r}0 \\
13 \\
17 \\
11 \\
2 \\
0\end{array}$ & $\begin{array}{r}0 \\
4 \\
6 \\
15 \\
14 \\
1\end{array}$ & $\begin{array}{r}1 \\
4 \\
4 \\
9 \\
12 \\
5\end{array}$ & $\begin{array}{r}1 \\
0 \\
3 \\
10 \\
11 \\
4\end{array}$ & $\begin{array}{r}2(1.4 \%) \\
21(14.3 \%) \\
20(20.4 \%) \\
45(30.6 \%) \\
39(26.5 \%) \\
10(6.8 \%)\end{array}$ \\
\hline 計 & $\begin{array}{c}43 \\
29.3 \%\end{array}$ & $\begin{array}{c}40 \\
27.2 \%\end{array}$ & $\begin{array}{c}35 \\
23.8 \%\end{array}$ & $\begin{array}{c}29 \\
19.7 \%\end{array}$ & 147 \\
\hline 平均年 令 & $\begin{array}{l}34.3 才 \\
\pm 8.6\end{array}$ & $\begin{aligned} & 43.8 才 \\
\pm & 10.1\end{aligned}$ & $\begin{aligned} & 46.9 才 \\
\pm & 12.6\end{aligned}$ & $\begin{array}{r}48.6 才 \\
\pm 10.0\end{array}$ & \\
\hline
\end{tabular}

表 3 症 例 の 職業 別 頻 度

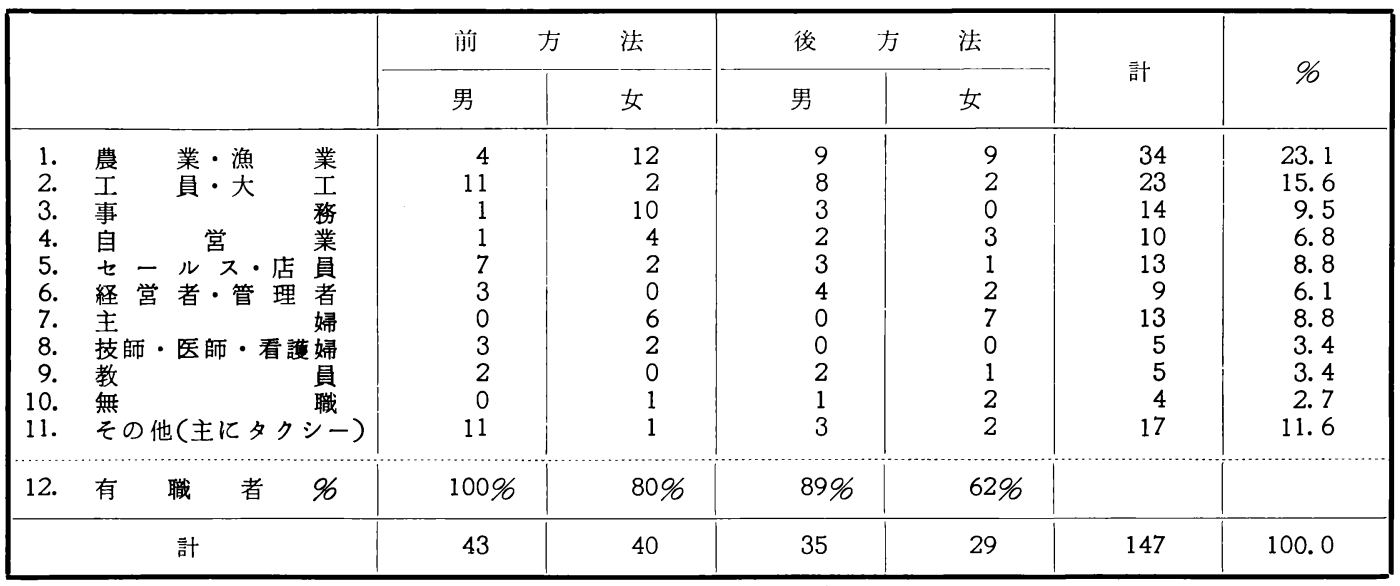

男性に比して有意（ $\mathrm{p}<0.01 ）$ に短期間であった（表 $4)$.

当院入院期間については, 術式では, 後方法群の男 性のみが, 前方法群に比して有意 $(\mathrm{p}<0.01)$ 亿短期 間であった. 男女間では, 後方法群の男性が, 前方法 の女性に比して有意 $(\mathrm{p}<0.01)$ 亿短期間であり, 同 性間では, 男女共後方法群の方が, 前方法群に比して 有意（ $\mathrm{p}<0.05 ）$ 亿短期間であった（表 4$)$.

退院後復職するまでの期間即ち, 自宅療養期間につ いては, 術式では, 前方法群の男性のみが, 後方法群 に比して有意 $(\mathrm{p}<0.01)$ に短期間であった. 男女間 では, 後方法群の男性が前方法群や後方法群の女性に 比して有意 $(\mathrm{p}<0.01)$ 亿最も短期間であり, 同性間 では, 前方法群の男性は, 後方法群化比して有意 $(\mathrm{p}$ <0.01）に短期間であった（表 4$)$.

当院入院期間 + 自宅療養期間, 即ち今回の手術のた
めの入院から復職するまでの期間については, 術式で は, 前方法群は男女共, 後方法群の男性に比して有意 （ $\mathrm{p}<0.05 ）$ に長期間であった. 男女間では, 前方 法群の 男性が，同方法群の女性に比して有意 $(\mathrm{p}<$ 0.01）に短期間であり, 後方法群の男女間には, 有意 差はなかった. また, 後方法群の男性は, 前方法群の 女性に比して有意 $(\mathrm{p}<0.01)$ 亿短期間であった. 同 性間では, 前方法群の男性は, 後方法群の男性に比し て有意 $(\mathrm{p}<0.01)$ 亿短期間であった（表 4$)$.

経済的損失月数については，本人の平均月収または 年収を基準に回答してもらった．表 4 亿示すように， 前方法群男性 7.4, 女性 8. 3, 後方法群男性 5.6, 女性 20.3 ケ月の損となっている. 統計学的には, 後方法群 の女性が他より有意に経済的損失を受けていることに なるが，その内容を検討してみると，その中 $3 \sim 10$ 年 という損失月数を回答している4 例があり，てれは今 
表 4 平均月数 $\pm \mathrm{S} \mathrm{D}$

\begin{tabular}{|c|c|c|c|c|c|}
\hline & \multicolumn{2}{|c|}{ 前 方 法 } & \multicolumn{2}{|c|}{ 後 方 法 } \\
\hline & & 男 & 女 & 男 & 女 \\
\hline \multicolumn{2}{|c|}{ 罹 病 期 間 } & $\begin{array}{r}42.4 \\
\pm 43.4\end{array}$ & $\begin{array}{r}46.0 \\
\pm 40.9\end{array}$ & $\begin{array}{r}20.7 \\
\pm 25.8\end{array}$ & $\begin{array}{r}67.5 \\
+83.3\end{array}$ \\
\hline \multirow{3}{*}{$\begin{array}{l}\text { 治 } \\
\text { 療 } \\
\text { 期 } \\
\text { 間 }\end{array}$} & 外来 & $\begin{array}{r}11.6 \\
\pm 22.5\end{array}$ & $\begin{array}{r}11.9 \\
\pm 13.4\end{array}$ & $\begin{array}{r}19.0 \\
\pm 48.3\end{array}$ & $\begin{array}{r}32.1 \\
\pm 40.9\end{array}$ \\
\hline & 他院入院 & $\begin{array}{r}2.3 \\
\pm \quad 1.2\end{array}$ & $\begin{array}{r}6.9 \\
\pm 11.9\end{array}$ & $\begin{array}{r}6.4 \\
\pm \quad 8.1\end{array}$ & $\begin{array}{r}5.6 \\
+5.2\end{array}$ \\
\hline & 当院入院 & $\begin{array}{r}4.3 \\
+1.9\end{array}$ & $\begin{array}{r}4.4 \\
\pm \quad 2.0\end{array}$ & $\begin{array}{r}2.3 \\
\pm \quad 1.0\end{array}$ & $\begin{array}{r}3.4 \\
+\quad 2.9\end{array}$ \\
\hline \multicolumn{2}{|c|}{ 社会復帰まで } & $\begin{array}{r}2.8 \\
\pm 2.6\end{array}$ & $\begin{array}{r}6.1 \\
\pm 6.7\end{array}$ & $\begin{array}{r}3.5 \\
+3.5\end{array}$ & $\begin{array}{r}5.3 \\
+7.4\end{array}$ \\
\hline \multicolumn{2}{|c|}{$\begin{array}{l}\text { 経済的 } \\
\text { 損失月数 }\end{array}$} & $\begin{array}{r}7.4 \\
+6.5\end{array}$ & $\begin{array}{r}8.3 \\
\pm 7.5\end{array}$ & $\begin{array}{r}5.6 \\
+6.3\end{array}$ & $\begin{array}{r}20.3 \\
\pm 32.7\end{array}$ \\
\hline \multicolumn{2}{|c|}{ 術後経過期間 } & $\begin{array}{r}21.2 \\
\pm \quad 6.8\end{array}$ & $\begin{array}{r}23.3 \\
+\quad 6.1\end{array}$ & $\begin{array}{r}24.2 \\
\pm \quad 5.7\end{array}$ & $\begin{array}{r}22.8 \\
+\quad 4.7\end{array}$ \\
\hline
\end{tabular}

回の手術前後に受けた損失以外に, 非常に長い罹病期 間中の損失を回答しているあのであり，乙の 4 例を除 外すると, 後方法群の女性の経済的損失月数は, 平均 $5.5 \pm 3.8$ ケ月となり, 結局経済的損失には, 術式, 男 女別，同性間全てにおいて特に有意差はみられなかっ た. しかしいずれにせよ手術前後に仕事を休んだため に被った経済的損失は, 平均 $6 \sim 8$ ケ月間という多大 なあのであることがわかった.

残存腰部症状による評価と, 本人の手術に対する満 足度については, 表 5 ・6 亿示す. 評価については, 良以上と可以下に分けてみると, 術式, 術式別の男女 間や，術式別にみた同性間共に有意差はみられなかっ た. 一方満足度については, 満足しているの口) 以上 と，しないよりよかったの八）以下について分けてみ ると, 術式や, また, 術式別の男女間にも有意差はみ られなかったが, 術式別の同性間では, 女性において

表 5 腰部症状による評価

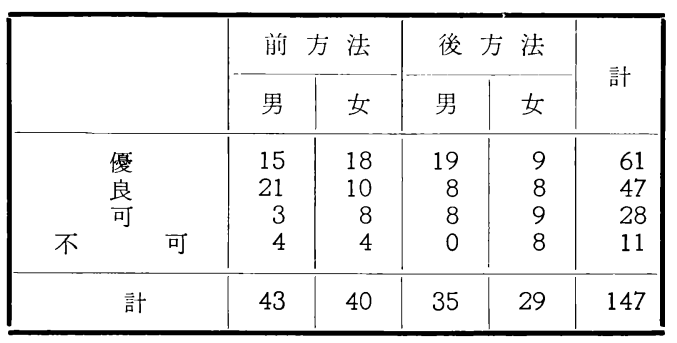

表 6 本人の手術に対する満足度

\begin{tabular}{|c|c|c|c|c|c|c|}
\hline & & \multicolumn{2}{|c|}{ 前 方 法 } & \multicolumn{2}{|c|}{ 後 方 法 } & \multirow{2}{*}{ 計 } \\
\hline & & 男 & 女 & 男 & 女 & \\
\hline & 明 & $\begin{array}{r}9 \\
17 \\
12 \\
4 \\
1 \\
0\end{array}$ & $\begin{array}{r}11 \\
18 \\
8 \\
0 \\
2 \\
1\end{array}$ & $\begin{array}{r}8 \\
15 \\
8 \\
2 \\
2 \\
0\end{array}$ & $\begin{array}{r}6 \\
7 \\
11 \\
2 \\
3 \\
0\end{array}$ & $\begin{array}{r}34 \\
56 \\
39 \\
8 \\
8 \\
2\end{array}$ \\
\hline & & 43 & 40 & 35 & 29 & 147 \\
\hline
\end{tabular}

は, 前方法の方が有意 $(\mathrm{p}<0.05)$ に満足度が高かっ た.

術式別, 男女別にみて, 評価之満足度との間には, 後方法の女性例を除いて，有意（ $\mathrm{p}<0.05 ）$ の関係が みられた（表 7 ). 即ち後方法の女性を除いては, 評 価と満足度との間には, 有意の関係がみられるととに なる・

表 7 評価と満足度との関係

\begin{tabular}{|c|c|c|c|c|c|c|c|c|}
\hline & & & 1 & 口 & 八 & $=$ & ホ & 計 \\
\hline \multirow[t]{2}{*}{ 前 } & \multirow[t]{2}{*}{ 男 } & $\begin{array}{c}\text { 優 }^{\text {良 }} \\
\text { 可可 }\end{array}$ & $\begin{array}{l}8 \\
1 \\
0 \\
0\end{array}$ & $\begin{array}{r}4 \\
12 \\
1 \\
0\end{array}$ & $\begin{array}{l}3 \\
6 \\
2 \\
1\end{array}$ & $\begin{array}{l}1 \\
2 \\
0 \\
1\end{array}$ & $\begin{array}{l}0 \\
0 \\
0 \\
1\end{array}$ & $\begin{array}{r}16 \\
21 \\
3 \\
3\end{array}$ \\
\hline & & 計 & 9 & 17 & 12 & 4 & 1 & 43 \\
\hline \multirow[t]{2}{*}{ 法 } & \multirow[t]{2}{*}{ 女 } & 不 $^{\frac{\text { 優 }^{\text {苛 }}}{}}$ & $\begin{array}{l}9 \\
1 \\
1 \\
0\end{array}$ & $\begin{array}{l}7 \\
7 \\
2 \\
2\end{array}$ & $\begin{array}{l}2 \\
1 \\
3 \\
2\end{array}$ & $\begin{array}{l}0 \\
0 \\
0 \\
0\end{array}$ & $\begin{array}{l}0 \\
0 \\
2 \\
0\end{array}$ & $\begin{array}{r}18 \\
9 \\
8 \\
4\end{array}$ \\
\hline & & 計 & 11 & 18 & 8 & 0 & 2 & 39 \\
\hline \multirow[t]{4}{*}{ 後 } & \multirow[t]{2}{*}{ 男 } & $\begin{array}{c}\text { 優 }^{\text {良 }} \\
{ }^{\text {可可 }}\end{array}$ & $\begin{array}{l}7 \\
1 \\
0 \\
0\end{array}$ & $\begin{array}{r}10 \\
3 \\
2 \\
0\end{array}$ & $\begin{array}{l}2 \\
3 \\
3 \\
0\end{array}$ & $\begin{array}{l}0 \\
1 \\
1 \\
0\end{array}$ & $\begin{array}{l}0 \\
0 \\
2 \\
0\end{array}$ & $\begin{array}{r}19 \\
8 \\
8 \\
0\end{array}$ \\
\hline & & 計 & 8 & 15 & 8 & 2 & 2 & 35 \\
\hline & \multirow[t]{2}{*}{ 女 } & $\begin{array}{c}\text { 優 } \\
\text { 良 } \\
\text { 不 }\end{array}$ & $\begin{array}{l}4 \\
1 \\
0 \\
1\end{array}$ & $\begin{array}{l}3 \\
2 \\
2 \\
0\end{array}$ & $\begin{array}{l}2 \\
4 \\
5 \\
0\end{array}$ & $\begin{array}{l}0 \\
1 \\
1 \\
0\end{array}$ & $\begin{array}{l}0 \\
0 \\
1 \\
2\end{array}$ & $\begin{array}{l}9 \\
8 \\
9 \\
3\end{array}$ \\
\hline & & 計 & 6 & 7 & 11 & 2 & 3 & 29 \\
\hline
\end{tabular}

疾患別では, 腰部椎間板症+分離症（前方法）のみ は，評価と満足度との間には有意 $\left(\mathrm{X}^{2}=4.1295 \mathrm{p}<\right.$ 0.05）の関係がみられた（表 8) が，他の疾患では, 有意な関係がみられなかった. また, 評価や満足度 
表 8 評価と満足度との関係（各疾患別, 術式別)

（前方法による）

\begin{tabular}{|c|c|c|c|c|c|c|c|c|}
\hline & & & 1 & 口 & 八 & $=$ & ホ & 計 \\
\hline \multirow{4}{*}{$\begin{array}{l}\text { 腰 } \\
\text { 部 } \\
\text { 椎 } \\
\text { 間 } \\
\text { 板 } \\
\text { 症 } \\
\text { と } \\
\text { 分 } \\
\text { 離 } \\
\text { 症 }\end{array}$} & \multirow[t]{2}{*}{ 男 } & $\begin{array}{c}\text { 優 } \\
\text { 良 }^{\text {不 }}{ }^{\text {可 }}\end{array}$ & $\begin{array}{l}5 \\
1 \\
0 \\
0\end{array}$ & $\begin{array}{r}2 \\
10 \\
1 \\
0\end{array}$ & $\begin{array}{l}3 \\
5 \\
2 \\
1\end{array}$ & $\begin{array}{l}1 \\
2 \\
0 \\
1\end{array}$ & $\begin{array}{l}0 \\
0 \\
0 \\
1\end{array}$ & $\begin{array}{r}11 \\
18 \\
3 \\
3\end{array}$ \\
\hline & & 計 & 6 & 13 & 11 & 4 & 1 & 35 \\
\hline & \multirow[t]{2}{*}{ 女 } & $\begin{array}{c}\text { 優 }^{\text {良 }} \\
\text { 不 }^{\text {可 }}\end{array}$ & $\begin{array}{l}5 \\
1 \\
0 \\
0\end{array}$ & $\begin{array}{l}4 \\
5 \\
0 \\
1\end{array}$ & $\begin{array}{l}2 \\
0 \\
1 \\
0\end{array}$ & $\begin{array}{l}0 \\
0 \\
0 \\
0\end{array}$ & $\begin{array}{l}0 \\
0 \\
2 \\
0\end{array}$ & $\begin{array}{r}11 \\
6 \\
3 \\
1\end{array}$ \\
\hline & & 計 & 6 & 10 & 3 & 0 & 2 & 21 \\
\hline
\end{tabular}

表 9 健康保険別症例内訳（術式別）

\begin{tabular}{|c|c|c|c|c|c|}
\hline & \multicolumn{2}{|c|}{ 前 方 法 } & \multicolumn{2}{|c|}{ 後 方 法 } \\
\hline & & 男 & 女 & 男 & 女 \\
\hline $\begin{array}{l}\text { 社 } \\
\text { 国 } \\
\text { 社 } \\
\text { 労 } \\
\text { 生 }\end{array}$ & $\begin{array}{r}\text { - 本 } \\
\text { - 保 } \\
\text { 家 } \\
\text { 保 }\end{array}$ & $\begin{array}{r}37 \\
6 \\
0 \\
0 \\
0\end{array}$ & $\begin{array}{r}16 \\
21 \\
2 \\
0 \\
1\end{array}$ & $\begin{array}{r}18 \\
16 \\
0 \\
1 \\
0\end{array}$ & $\begin{array}{r}7 \\
16 \\
4 \\
0 \\
2\end{array}$ \\
\hline & 計 & 43 & 40 & 35 & 29 \\
\hline
\end{tabular}

と, 罹病期間, 外来治療期間, 入院治療期間, 復職ま での期間や経済的損失月数との間には，有意の関係は みられなかった。

参考までに, 健康保険別症例内訳を表 9 に示す. 職 業別頻度で述べたように, 社会保険本人と農漁業の国 民保険がほとんどで, 全症例の有職率 $88.4 \%$ と高い.

生命保険等の入院給付金等の収入があった者は, 前 方法の男性 $70 \%$, 女性 $45 \%$, 後方法の男性 $51 \%$, 女性 $45 \%$ であった. しかし，乙れらと経齐的損失月
数, 評価, 満足度との間には有意の関係はみられなか った.

職業変更について（表 10）術後軽作業労働に職業変 更した者は，合計 26 名（17.8\%）にみられた．前方 法 16 例 $(19.3 \%)$, 後方法 10 名 (15.6\%) であり, 経済的損失月数については，術式，男女間や同性間に 有意差はなく, 職業変更なしの者とも有意差はなかっ た. また評価や満足度との関係もなかった。

\section{考察}

腰痛疾患に対する手術的療法により, 種々の不利益 を被むることに関して, 積極的に論じた文献は, 初め に述べたように少ない. 術前の長期の䍜病期間には, 相当の経済的，心理的マイナスの影響を受けていると 思われる. Spangfort は, 椎間板ヘルニア 1386 症例 の平均罹病期間 3.8 年と報告しており，乙の点に関し ては我々の症例でもほぼ同じである. 経済的損失月数 については, 今回の手術に関連した術前後の期間のマ イナスを，平均月収または年収を基準に回答してもら ったが, 術式による差, 男女差や同性間には推計学的 に有意差はみられなかった。しかし，乙の経済的損失 は, 平均 6 〜 8 ケ月よなっおり, 入院期間と復職ま での期間を合算した平均期間 6〜10 ケ月を考慮する と，多大の経済的損失を受けているととがわかる. そ して，乙の経齐的損失は，手術に対する評価や満足度 とは, 相関がうすい. 後方法の女性例のみに有意の差 をもって不満足例がみられたが，経齐的損失月数では 有意差はなかったことからあ，相関はないと云える. いずれにしても, 発症から術後復職するまで相当の長 期間苦しんでいることが同え，その間に受けた心理的 側面は測りようがないが，少なくとも経済的損失は多 大である.

表 10 職業 変 更 (術後軽作業労㗢に)

\begin{tabular}{|c|c|c|c|c|c|c|c|c|c|}
\hline & & & & & & 前 & 法 & 後 & 法 \\
\hline & & & & & & 男 & 女 & 男 & 女 \\
\hline $\begin{array}{l}\text { 変 } \\
\text { 平 } \\
\text { 経 } \\
\text { 罹 } \\
\text { 外 } \\
\text { 他 } \\
\text { 当 } \\
\text { 復 }\end{array}$ & $\begin{array}{l}\text { 済 } \\
\text { 来 } \\
\text { 院 } \\
\text { 院 } \\
\text { 職 }\end{array}$ & $\begin{array}{l}\text { 更 } \\
\text { 均 } \\
\text { 的 損 } \\
\text { 病 } \\
\text { 治 } \\
\text { 入 } \\
\text { あ } \\
\text { ま }\end{array}$ & $\begin{array}{l}\text { 人 } \\
\text { 年 } \\
\text { 失 } \\
\text { 期 } \\
\text { 院 } \\
\text { 院 } \\
\text { の }\end{array}$ & $\begin{array}{c}\text { 月 } \\
\text { 期 } \\
\text { 期 } \\
\text { 期 } \\
\text { 期 }\end{array}$ & $\begin{array}{l}\text { 数 } \\
\text { 令 } \\
\text { 数 } \\
\text { 間 } \\
\text { 間 } \\
\text { 間 } \\
\text { 間 } \\
\text { 間 }\end{array}$ & $\begin{array}{r}7.3 \%) \\
22.6 \pm 8.2 \\
10.2 \mathrm{M} \pm 8.4 \\
38.4 \mathrm{M} \pm 27.6 \\
8.7 \mathrm{M} \pm 10.4 \\
1.8 \mathrm{M} \pm 0.4 \\
4.0 \mathrm{M} \pm 2.8 \\
4.1 \mathrm{M} \pm 3.0\end{array}$ & $\begin{array}{r}9(22.5 \%) \\
44.2 \pm 7.5 \\
12.6 \mathrm{M} \pm 10.3 \\
39.6 \mathrm{M} \pm 32.4 \\
11.5 \mathrm{M} \pm 11.6 \\
2.3 \mathrm{M} \pm 0.6 \\
4.9 \mathrm{M} \pm 2.8 \\
13.6 \mathrm{M} \pm 8.7\end{array}$ & $\begin{array}{r}6 \\
34.3 \pm 17.1 \%) \\
8.8 \mathrm{M} \pm 8.6 \\
24 \mathrm{M} \pm 27.6 \\
8.0 \mathrm{M} \pm 6.7 \\
5.5 \mathrm{M} \pm 1.2 \\
2.7 \mathrm{M} \pm 1.2 \\
5.7 \mathrm{M} \pm 2.1\end{array}$ & $\begin{array}{r}4(13.8 \%) \\
43.8 \pm 6.3 \\
17.0 \mathrm{M} \pm 17.1 \\
22.5 \mathrm{M} \pm 15.6 \\
18.7 \mathrm{M} \pm 11.0 \\
0 \mathrm{M} \\
\text { 4. } 8 \mathrm{M} \pm 5.0 \\
15.3 \mathrm{M} \pm 13.7\end{array}$ \\
\hline
\end{tabular}

* 術後重学働に職業変更 3 人あり. (前方法男性例) 
術後, 何らかの理由で, 軽作業に職業変更したもの は，桐田は，149 例中 7 例 $4.6 \%$ と報告しているが， 我々の 147 例中 26 例 $17.8 \%$, その症例の疾患構成 が違っているとはいえ，多い. この職業変更した者の 経済的損失月数は（表 10）職業変更なしの者と比較し て有意差はなかった. また，評価や満足度との相関も なく治療期間，入院期間，復職までの期間等との相関 あなかった，その変更した理由を本人が回答している ように，意識的に腰をかばったり，職場の配慮で軽作 業労㗢に回してあらったりした者が多かった.

手術に対する心理反応としての満足度については， 女性間では後方法の方が，前方法に対して満足度が低 くなっていたが, 後方法施行の女性では, 評価と満足 度の相関がないてとから判断して, 評価はよくても, マイナスの心理反応を示している. 即ち, 罹病期間, 治療期間，経済的影響因子，年令因子や疾患の種類に おいては，有意の関連がなく，乙の後方法群の女性で は，有職率が最も低いことがマイナスの心理反応に影 響を与えていると考えられる。

Tunturi らは, 腰仙椎固定術を施行した 133 例に つき Social factor をアンケート調査しているが, 術後成績と術後労働能力との間に統計的に有意の関係 を報告している．そしてその因子として，教育レベ ル, 術前の職種, 筋肉労働者, 子供の数, 居住の大き さを指摘し，腰痛患者の包括的リハビリテーションの 重要性を論じている，我々外科医がメスを持つ場合， これら社会的経済的因子まで考慮して，Tunturi の 結びの言葉を肝に命じておくべきであろう.

\section{ま と め}

1. 腰痛が個人の生活特に経済的に及ぼすマイナス 因子としては，罹病期間，入院期間，自宅療養期間の 長さが考えられた．但し，経済的損失では，術式や男
女間に特に有意差を認めなかった.

2.しかし，経済的損失そのものは，術式や男女差 に関係なく，多大の損失を与えていた。

3. 術後軽作業への職業変更は, 前方法 $19.3 \%$, 後方法 $15.6 \%$ にられ，その主な理由は，身体(腰) の為であり，評価や満足度とは関係なかった．また， 職なしの者と比較して，特に有意差はなかった。

4. 腰痛に刘する術式で, 前方法と後方法との間に は，評価や満足度において有意差はなかった，但し， 女性で後方法を選択する際には，職業因子を考慮する 必要がある.

5. 入院期間や社会復帰までの期間では，女性に比 べて，男性の方が短期間であり，より早く復職してい る. 男性間では，椎体固定という術式の影響で，前方 法の男性の方が後方法より復職は後れている.

6. 腰痛疾患が個人の生活に及ぼす経済的影響を裏 返せば，社会保険を通じて，間接に社会への経済的影 響を反影しているということを認識して， case by case で最善を尽し，より早期の社会復帰を期すべき であろう.

\section{参考文献}

1) A. Naylor, Bradford: J. Bone Joint Surg., 56-B : 17-29, 1974.

2) Erik V. Spangfort: Acta Orthop. Scand. (Suppl.) No. 142, 18-19, 1972.

3）桐田良人・他：日整会誌, Vol. 47, No. 12, 1088-1089, 1973.

4) Tunturi, T. and Pätiälä, H. : Scand J. of Rehab. Med. Vol. 12, No. 1, 17-23, 1980.

質 問佐賀医大 渡辺 英夫

男性が 女性より再就職がはやい 理由は何でしょう か. 